\title{
Cross-transmission studies of Perkinsus karlssoni (Apicomplexa) from bay scallops Argopecten irradians to native Atlantic Canadian shellfish species
}

\author{
S. K. Whyte ${ }^{1}$, R. J. Cawthorn ${ }^{1}$, S. E. McGladdery ${ }^{3}$, R. J. MacMillan ${ }^{1}$, \\ D. M. Montgomery ${ }^{2}$ \\ ${ }^{1}$ Department of Pathology and Microbiology, ${ }^{2}$ Department of Health Management, Atlantic Veterinary College, \\ University of Prince Edward Island, Charlottetown, Prince Edward Island, Canada C1A 4P3 \\ ${ }^{3}$ Department of Fisheries and Oceans, PO Box 5030, Moncton, New Brunswick, Canada E1C 9B6
}

\begin{abstract}
The potential for cross-transmission of Perkinsus karlsson from bay scallops Argopecten irradians to various native Atlantic Canadian species of shellfish was investigated. Lateral proximal transmission was investigated whereby infected moribund bay scallops wore maintained with uninfected individuals of other bivalve species in a recirculating artificial seawater system. There was no evidence, either histologically or by thioglycollate culture, to conclude that transmission of $P$. karlssoni had occurred over the 22 mo study period. zoosporanglal stages of $P$. karissoni were observed in both the male and female gonads of the bay scallop, and the possibility of parasite release during spawning is discussed. Shellfish mortality over the study period was attributed to intolerance of the temperature and salinity ranges of the holding system
\end{abstract}

KEY WORDS: Argopecten irradians Bay scallop · Cross-transmission Perkinsus karlssoni

\section{INTRODUCTION}

The bay scallop Argopecten irradians is a non-indigenous species to Canada (Gutsell 1930, Clarke 1965) but has been introduced legally into Atlantic Canada on 2 separate occasions, in 1978 and 1989, for the purpose of establishing a bay scallop fishery. Since the adults die shortly after spawning the bay scallop presents itself as an annual aquaculture species in Atlantic Canada (Courturier 1990). The adults spawn in a temperature-controlled hatchery environment and the spat are transferred to open water. During the summer spat undergo rapid growth, reaching adult size by autumn of the same year. At that point they are marketed, although some are retained by the producer to become the broodstock for the following year's spat production.

By 1989, private hatcheries in Nova Scotia had produced sufficient quantities of commercial seed which could be moved to Prince Edward lsland (PEI), initially for grow-out purposes but with a future view to establishing a fishery. In May and June 1989, in accordance with government guidelines for the reduction of risks associated with the introduction and transfer of live aquatic organisms, samples of broodstock were submitted for routine histological examination prior to their entry into PEI. A previously undescribed apicomplexan parasite, Perkinsus karlssoni, was identified (McGladdery et al. 1991) and found to have characteristics related to pathogenic members of the family Perkinsidae (Levine 1978).

Members of this family are known to have a major impact on various shellfish industries throughout the world: Perkinsus marinus, a pathogen of eastern oyster Crassostrea virginica (Andrews 1988); $P$. olseni, pathogenic to blacklip abalone Haliotis ruber (Lester \& Davis 1981); and P. atlanticus, a parasite of the clam Ruditapes decussatus (Azevedo 1989). Since no Perkinsus 
$\mathrm{sp}$. has been detected in native Canadian shellfish species to date, concern was raised about the possible transfer of this parasite to native shellfish stocks.

This paper describes the results of a transmission study carried out in a recirculation system and initiated to investigate the potential transmission of Perkinsus karlssoni from infected bay scallops to a variety of native shellfish species.

\section{MATERIALS AND METHODS}

Shellfish. Juvenile, native shellfish species were collected from 3 different sources during the period from late November to mid December 1990. These included: 289 blue mussels Mytilus edulis; 260 eastern oysters Crassostrea virginica; 252 quahaugs Mercenaria mercenaria; 278 sea scallops Placopecten magellanicus from Chester, Nova Scotia; and 85 soft-shell clams $M y a$ arenaria from the East River, PEI. All species were transported to the quarantine facility at the Atlantic Veterinary College (AVC), PEI, where a random sample ( $10 \%$ of total number) of each species was removed and screened for disease agents including Perkinsus karlssoni; the screening was done to ensure a reference base of what was present at time zero. Tissue samples (digestive gland, rectum, gill, mantle) were extracted and processed for histological examination (Howard \& Smith 1983) and thioglycollate culture (Ray 1966)

In February 1991, 500 juvenile bay scallops Argopecten irradians were transferred from the provincial hatchery at Ellerslie, PEI, to AVC. A random sample ( $5 \%$ of total number) was removed to assess the disease status of these scallops. Tissues were extracted, as before, for histological examination and thioglycollate culture. Infection of bay scallops by Perkinsus karlssoni was confirmed by production of zoospores, and prevalence of $P$. Karlssoni in bay scallops was assessed at $100 \%$. Once the presence of infection was determined, the remaining bay scallops were equally distributed into 5 different experimental tank units (MacMillan et al. in press). Following confirmation that no disease agent was present in the native shellfish species, individuals were separated by species into 5 different control tank units (MacMillan et al. in press), acclimatized and maintained thereafter at temperatures of 17 to $24^{\circ} \mathrm{C}$ and salinities of 27 to $32 \%$.

Experimental design. Each of the native species was divided into 2 groups: one group was transferred into the different experimental tanks containing bay scallops and the second group remained in the control tank system. There were more individuals in the control group for each of the shellfish species than the experimental group to compensate for the differences in density, due to the lack of bay scallops in the control system. This resulted from a failure to locate a stock of bay scallops that were free of Perkinsus karlssoni infection to act as control individuals.

The shellfish were maintained in a recirculating, artificial seawater (Instant Ocean), quarantine system as described by MacMillan et al. (in press) and fed daily with cultured algae (Chaetoceros gracilis and Tahitian isochrysis) and SDA • [Spray Dried Algae (Tetraselmis), Cell Systems Ltd, Orwell House, Cowley Road, Cambridge CB4 4WY, UK]. Water temperatures were maintained between 17 and $24^{\circ} \mathrm{C}$ and salinities between 27 and $32 \%$. Mortalities were recorded daily and dead individuals removed for histological examination and thioglycollate culture. Bay scallop mortalities were also recorded daily but the moribund bay scallops were left in situ until all the tissue had disintegrated, thus facilitating any potential parasite transfer.

Data collection and analysis. Random samples of 10 of each native species were removed every $60 \mathrm{~d}$ starting in March 1991 from both the control and experimental tanks. Tissues were processed for histology and thioglycollate culture. Random samples of 10 bay scallops were removed from experimental tanks every $60 \mathrm{~d}$ and also processed for histology and thioglycollate culture.

The statistical analysis of the data from March 1991 to December 1992 was performed using the Statistical Analysis System (SAS 1987). The behaviour of the dichotomous response outcome variable (mortality/survival) was modelled using survival analysis techniques. Factors of interest were then investigated using logistic regression procedures.

\section{RESULTS}

Histological examination and thioglycollate culture of each of the native shellfish species revealed no sign of Perkinsus karlssoni. Histological examination and thioglycollate culture of the bay scallops held in proximity with the native shellfish species indicated that they remained infected with $P$. karlssoni throughout the experimental period. In addition, histology revealed that the bay scallops matured over the course of the experiment and $P$. karlssoni lesions were present in both the male (Fig. 1a) and female (Fig. 1b) gonads.

The mortality data for the 5 species exposed to bay scallops (eastern oysters, sea scallops, quahaugs, softshelled clams and blue mussels) was analyzed.

Initially, a non-parametric method of survival analysis was performed on the data for each species, com-

\footnotetext{
- No longer available
} 
Fig. 1 Perkinsus karlssoni. Parasite lesion ( $p$ ) within the interstitial tissue of (a) a mature bay scallop testis, and (b) a mature bay scallop ovary, examined by light microscopy using $\mathrm{H} \& \mathrm{E}$. Scale bars $=14 \mu \mathrm{m}$

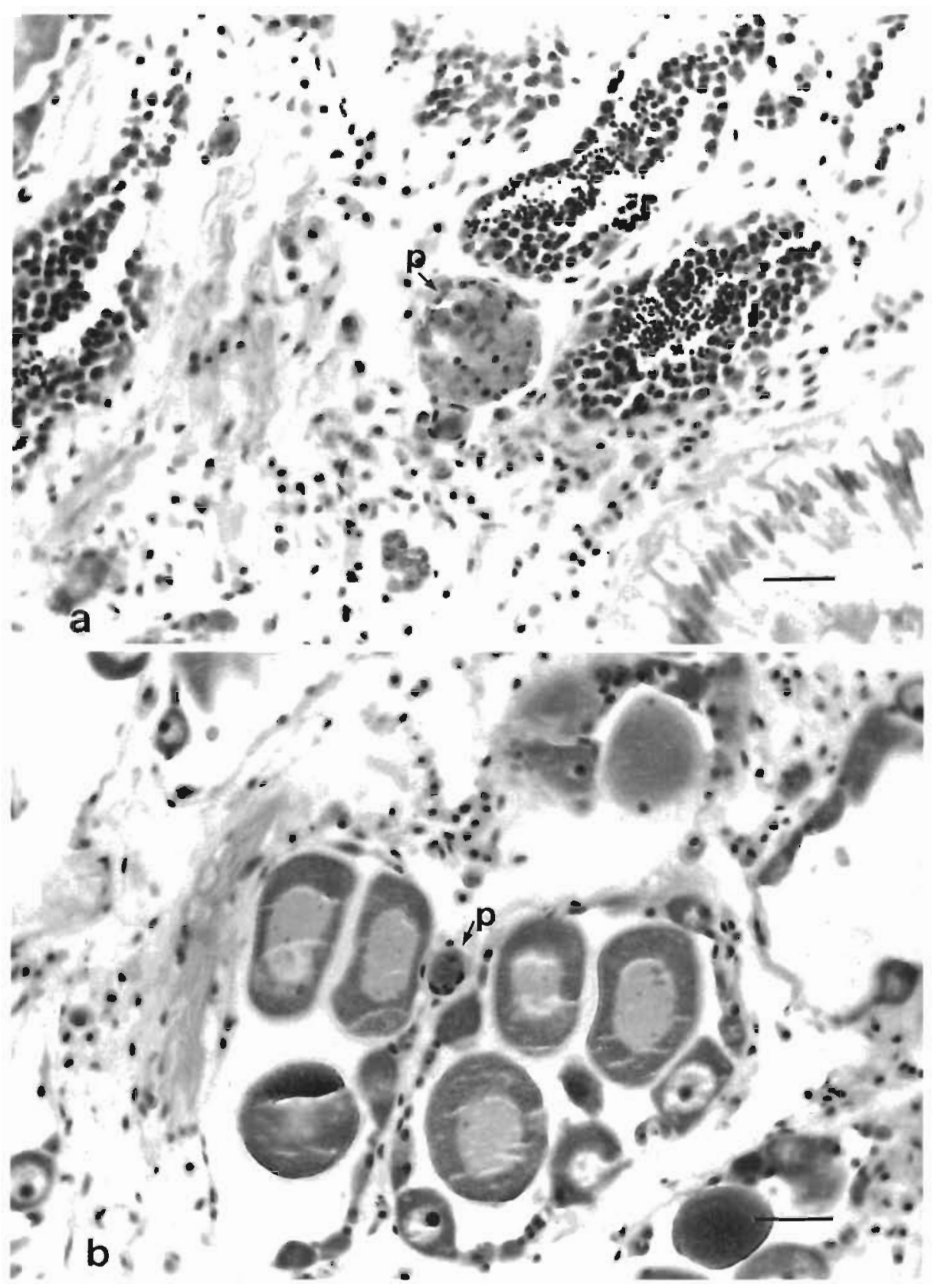

paring the survival rates of control and experimental animals over a period of 22 mo. A Wilcoxon Rank Sum test was used to test for significance. No significant difference was observed between control and experimental animals for both blue mussels $(p>0.05)$ and softshelled clams $(p>0.05)$. There was, however, a significant increase in survival time of control groups compared with experimental groups for sea scallops $(p<0.05)$, quahaugs $(p<0.01)$ and eastern oysters $(p<0.05)$

Further analysis of sea scallop, quahaug and eastern oyster results indicated that all the data fitted a Weibull survival distribution. Using this model, the data for each species was analyzed to observe the effect of the presence of bay scallops, temperature and salinity on survival rate:

(1) Eastern oyster: Both temperature $(p<0.001)$ and salinity $(p<0.001)$ had a significant effect on oyster survival, but the presence of bay scallops did not $(p>0.05)$ once the temperature and salinity effects were taken into consideration.

(2) Quahaug: Only temperature had a significant effect on quahaug survival $(p<0.001)$. The presence of bay scallops, however, did not have an effect on sur- 

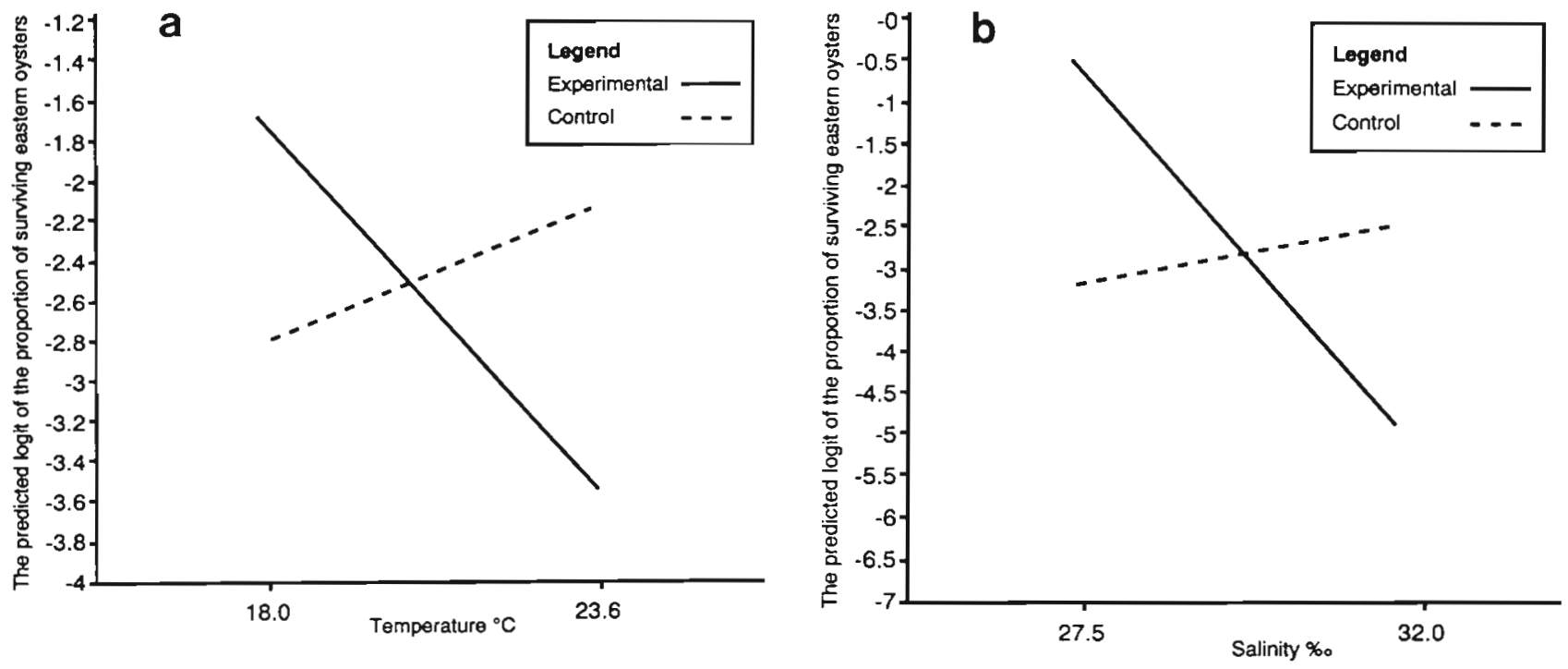

Fig. 2. (a) The predicted logit of the proportion of surviving eastern oysters at different temperatures while exposed to bay scallops infected with Perkinsus karlssoni. (b) The predicted logit of the proportion of surviving eastern oysters at different. salinities while exposed to bay scallops infected with $P$. karlssoni

vival once the effect of temperature was taken into consideration $(p>0.05)$.

(3) Sea scallop: Only temperature had a significant effect on sea scallop survival $(p<0.001)$. The presence of bay scallops also had a significant effect on sea scallop survival $(p<0.001)$.

An analysis of variance indicated that there was a significant difference between the control and experimental systems for both temperature $(p<0.001)$ and salinity $(p<0.001)$, both within a month and between months. A logistic regression analysis further indicated that the significant effects of temperature and salinity were linear in nature. A logit transformation of the data was performed to allow further insight into the effect of temperature and salinity on the control and experimental groups and to generate the estimated values for the parameters of interest:

(1) Eastern oyster: Temperature did not appear to have an effect on the control group, with the number of survivors remaining relatively constant over the temperature range experienced. The effect on the experimental group was more obvious, with fewer individuals surviving at higher temperatures $\left(23.6^{\circ} \mathrm{C}\right)$ than lower temperatures $\left(18.0^{\circ} \mathrm{C}\right.$ ) (Fig. 2a). Salinity had the same effect as temperature, with the control group remaining constant over the range of salinities experienced, but the experimental group demonstrating fewer survivors at higher salinities (32\%) compared with lower salinities (27.5\%) (Fig. 2b)

(2) Quahaug: Higher temperatures resulted in fewer individuals surviving in both the control and the experimental group, although the control group was not as obviously affected as the experimental group (Fig. 3).

(3) Sea scallop: Higher temperatures resulted in fewer individuals surviving in both control and experimental groups (Fig. 4).

\section{DISCUSSION}

The failure to detect the presence of Perkinsus karlssoni in any of the native shellfish species, either by histology or thioglycollate culture, suggests that the parasite had not been transmitted between bay scallops and the other species. McGladdery et al. (1993) also failed to demonstrate transmission of $P$. karlssoni from infected bay scallops to several native shellfish species using a parallel flow-through system. They did report that following spawning of infected bay scallops, the zoospore stage of the parasite was detectable among the progeny, apparently adhering to the surface of healthy $D$-stage larvae. Surface sterilization of the bay scallop eggs with a $1 \%$ iodophor solution failed to remove the parasite. When infected bay scallops and blue mussels were spawned in the same tank, the bay scallops became infected, but there was no evidence of cross-species transmission and the blue mussels remained free of infection (McGladdery et al. 1993). This is the first report of a Perkinsus sp. transmitting directly from infected broodstock to their offspring (McGladdery et al. 1993).

The lesions observed in the gonads of the bay scallops (Fig. 1a, b) were found only in the interstitial tis- 


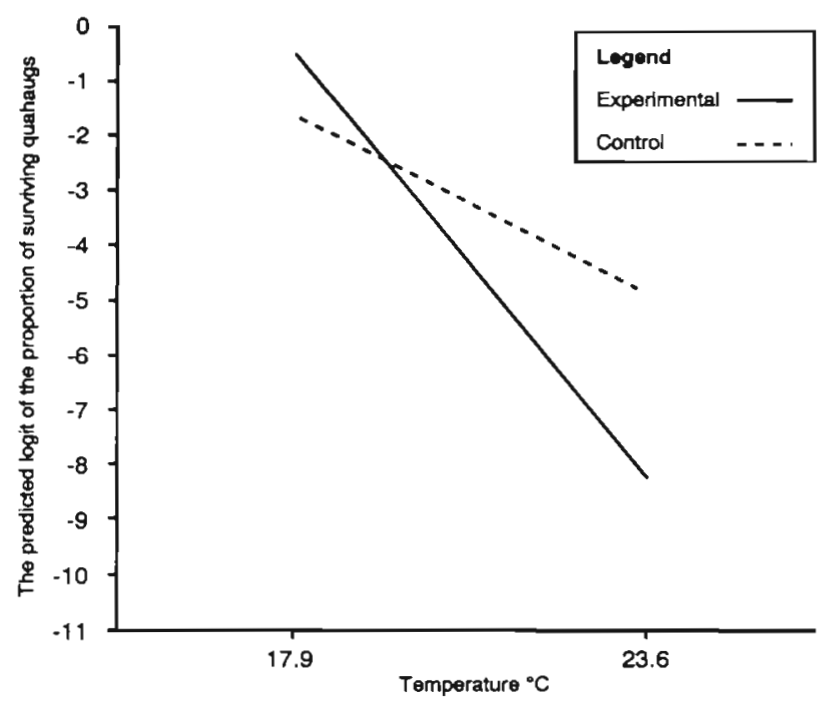

Fig. 3. The predicted logit of the proportion of surviving quahaugs at different temperatures while exposed to bay scallops infected with Perkinsus karlssoni

sue of the gonad and not in the ova or seminiferous tubules. Karlsson (1991) identified Perkinsus karlssoni within the gonads of bay scallops but inside individual ova, where a large proportion of the egg volume was replaced by the zoosporangial stage of the parasite. Infected eggs were associated with a marked inflammatory response by the bay scallop. As in the present study, McGladdery et al. (1993) did not observe infected ova in any of the bay scallops used in their experiments, suggesting that infection of the eggs themselves is a rare occurrence. Whether the bay scallops in this study actually spawned during the experimental period is not known since no moribund bay scallops were removed and processed for histology. Only healthy bay scallops were removed for histology and the moribund individuals were left in situ until all the tissue had disintegrated, thus facilitating any potential parasite transmission which may occur.

Failure to demonstrate cross-transmission of Perkinsus karlssoni, in laboratory or field conditions, to species other than the bay scallop suggests a strong host specificity. Indeed no transmission of $P$. karlssoni has been demonstrated in any of the areas where other bivalve species are cultured alongside bay scallops. The reasons for shellfish death in this study could not be attributed to parasite transmission but are concluded to be a result of the environmental conditions under which the shellfish were held. The 2 systems were significantly different in their temperature and salinity profiles throughout the experimental period, and this was attributed to the arrangement of the holding systems with respect to the heating vents in the quarantine room (MacMillan et al. in press). It is speculated that the difference between the systems led to

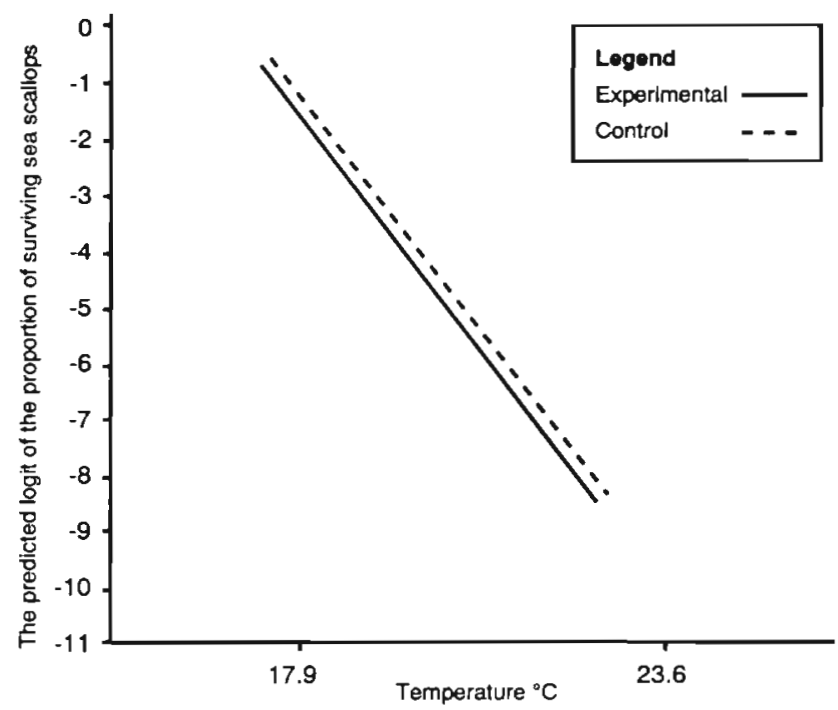

Fig. 4. The predicted logit of the proportion of surviving sea scallops at different temperatures while exposed to bay scallops infected with Perkinsus karlssoni

differences in the survival rates of the control and experimental groups. Survival rates of eastern oysters were affected by increasing temperatures and salinities within the system, although the control group was less affected than the experimental group (Fig. 2a, b). This pattern was repeated for the quahaugs (Fig. 3). In the case of the sea scallops it was apparent that the environmental conditions, particularly the temperature regime, were unsuitable to sustain life since all of the control group died within 4 mo of entry into the system and all of the experimental group died within 2 mo. The statistical analysis also demonstrated that the presence of the bay scallops had no effect on eastern oyster or quahaug survival but did have a deleterious effect on sea scallop survival despite the fact that the parasite was not transmitted. The reason for this is unclear, although it is possible that there was competition for food or that some other cohabitation factor was involved. It should be noted that MacMillan et al. (in press) reported the overall mean levels of nitrogenous waste (nitrate, nitrite and ammonia levels) and $\mathrm{pH}$ in both systems to be within acceptable levels for marine bivalves, as suggested by Spotte (1979). Indeed, MacMillan et al. (in press) concluded that the biological filter was adequate in providing optimal water quality for holding bivalves during the 2 yr study period. This would support the suggestion that the presence of decaying bay scallop tissue in the experimental system did not have any significant effect on eastern oyster or quahaug mortalities (Figs. 2a, b \& 3). It may also indicate that the deleterious influence of bay scallops on the sea scallops was not due to a deterioration in water quality caused by decaying bay scallop tissue.

Transmission in other Perkinsus spp., where known, 
is speculative; $P$ marinus has been shown to be transmitted between the same species from moribund hosts to neighbouring hosts, i.e. lateral proximal transmission (Ray 1954, Mackin 1962. Andrews 1965, 1988), and through the actions of predators and scavengers, such as the ectoparasitic gastropod Boonea impressa (White et al. 1987). It has been shown that B. impressa is capable of transmitting $P$. marinus between individual oysters under laboratory conditions (White et al. 1987). The importance of this organism, and any of the other named scavengers of oysters, as a reservoir of infection or alternate host for $P$. marinus in the field, however, remains to be demonstrated (Andrews 1988). Whatever the method of transmission it is generally accepted that dissemination is slow, sporadic and localized (White et al. 1987, Craig et al. 1989). For example, the spread of infection from reef to reef may take years to occur (Ray 1987). The distances required to prevent dissemination of the parasite from one oyster bed to another, however, are not known (Andrews 1988, Craig et al. 1989). P. marinus is believed to show strong host specificity (Lauckner 1983), but Andrews (1988) reported that, in addition to eastern oysters, it also infects the frond oyster Dendostrea frons and the crested oyster Ostrea equestris. Andrews (1988) also speculated that $P$. marinus would probably infect almost any species of oyster given a high enough dosage, although the degree of pathogenicity could vary between different species.

Perkinsus olseni has been reported to disseminate in the same way as $P$. marinus, from infected decaying blacklip abalone Haliotis ruber to uninfected neighbouring individuals (Lester \& Davis 1981). It has, however, also been successfully transmitted from the green lip abalone $H$. laevigata to 2 lamellibranch species (blood cockle Anadara trapezia and pearl oyster Pinctada sugillata), suggesting a less than rigid host specificity (Lester et al. 1990, O'Donoghue et al. 1991).

Several undescribed Perkinsus-like organisms have also been isolated from a variety of mollusc species (Ray 1954, da Ros \& Canzonier 1985, Perkins 1985. Goggin \& Lester 1987) although the number of potential Perkinsus species is unknown. Goggin et al. (1989), and, later, Lester et al. (1990) demonstrated the transmission of Perkinsus spp. from the gastropod host (Haliotis laevigata) to various bivalve species and vice versa. O'Donoghue et al. (1991) concluded that transmission of some Perkinsus spp. between different mollusc species inhabiting the same waters may be plausible.

Given the diversity of host specificity which occurs between the different species of Perkinsus, the importance of carrying out controlled transmission studies prior to introduction of new shellfish species is apparent. In the case of P. karlssoni no parasite transmission from bay scallops to native shellfish species resulted, suggesting a relatively rigid host specificity. As a result of these findings, a 2 yr moratorium on bay scallop culture was recently lifted. Since it was estimated that the existing bay scallop industries in the United States and China together produced over a hundred thousand tonnes of bay scallop annually in 1990 (Chew 1990), the lifting of the moratorium should enable the development of a potentially lucrative industry in Atlantic Canada.

Acknowledgements. This project was supported in part by funds awarded to R.J.C. from the DFO Atlantic Fisheries Adjustments Programme (AFAP) for Aquaculture, the Atlantic Canada Opportunities Agency (ACOA) and the Natural Sciences and Engineering Council (NSERC). We thank Mr Irwin Judson, Department of Fisheries and Aquaculture (PEI), Mr Paul Burleigh, Department of Fisheries and Aquaculture (PEI), Mr Jim Campbell, Holland College (PEI), and Mr Andy Schnare, SFT Ventures Ltd, Nova Scotia for their contributions to this project.

\section{LITERATURE CITED}

Andrews, J D. (1965). Infection experiments in nature with Dermocystidium marinum in Chesapeake Bay. Chesapeake Sci. 6: 60-67

Andrews, J. D. (1988). Epizootiology of the disease caused by the oyster pathogen Perkinsus marinus and its effect on the oyster industry. In: Fisher W. S. (ed.) Disease processes in marine bivalve molluscs. Am. Fish. Soc. Spec. Publ. 18: p. 47-63

Azevedo, C (1989). Fine structure of Perkinsus atlanticus n. sp. (Apicomplexa, Perkinsea) parasite of the clam Ruditapes decussatus from Portugal. J. Parasitol. 75(4): $627-635$

Chew, K. K. (1990). Global bivalve shellfish introductions. World Aquacult. 21(3): 9-22

Clarke, A. H. Jr (1965). The scallop super species Argopecten irradians (Lamarck). Malacalogia 2(2): 161-188

Couturier, C. (1990). Scallop aquaculture in Canada: fact or fantasy? World Aquacult. 21(2): 54-62

Craig, A., Powell, E. N., Fay, R. R., Brooks, J M. (1989). Distribution of Perkinsus marinus in Gulf Coast oyster populations. Estuaries 12(2): 82-91

da Ros, L., Canzonier, W. J. (1985), Perkinsus, a protistan threat to bivalve culture in the Mediterranean basin. Bull Eur. Ass. Fish Path. 5: 23-25

Goggin, C. L., Lester, R. J. G. (1987). Occurrence of Perkinsus species (Protozoa, Apicomplexa) in bivalves from the Great Barrier Reef. Dis. aquat. Org. 3: 113-117

Goggin, C. L., Sewell, K. B., Lester, R. J G. (1989). Crossinfection experiments with A.ustralian Perkinsus species Dis. aquat. Org. 7: 55-59

Gutsell, J. S. (1930). Natural history of the bay scallop Bull. U.S. Bur. Fish. 46: 569-632

Howard, D. W., Smith, C. S. (1983). Histological techniques for marine bivalve mollusks. NOAA Tech. Memo. NMFSF/NEC-25, Woods Hole, MA

Karlsson, J. D. (1991). Parasites of the bay scallop, Argopecten irradians (Lamarck, 1819). In: Shumway, S. E. (ed.) International compendium of scallop biology and culture. World Aquaculture Society and National Shellfisheries Association, Baton Rouge, LA, p. 180-190 
Lauckner, G. (1983). Diseases of Mollusca: Bivalvia. In: Kinne, O. (ed.) Diseases of marine animals, Vol. II, Bivalvia and Scaphopoda. Biologische Anstalt Helgoland, Hamburg, p. $477-961$

Lester, R. J. G., Davis G. H. G. (1981). A new Perkinsus species (Apicomplexa, Perkinsea) from the abalone Haliotis ruber. J. Invertebr. Pathol, 37: 181-187

Lester, R. J, G., Goggin, C. L., Sewell, K. B. (1990). Perkinsus in Australia. In: Perkins, F. O., Cheng, $T$ C. (eds.) Pathology in marine science. Academic Press, San Diego, p. $189-199$

Levine, N. D. (1978). Perkinsus gen. n. and other new taxa in the protozoan phylum Apicomplexa. Parasitology. 64(3): 549

Mackin, J. G. (1962). Oyster diseases caused by Dermocystidium marinum and other microorganisms in Louisiana. Publs Inst. mar. Sci. Univ. Texas 7: 132-229

MacMillan, R. J., Cawthorn, R. J., Whyte, S. K., Lyon, P. (in press). Design and maintenance of a closed, artificial seawater system for long term holding of bivalve species. Aquacult. Engng

McGladdery, S. E., Bradford, B. C., Scarratt, D. J. (1993). Investigations into the transmission of parasites of bay scallop, Argopecten irradians (Lamarck, 1819), during quarantine introduction to Canadian Atlantic waters. J. Shellfish Res. 12(1): 49-58

McGladdery, S. E., Cawthorn, R. J., Bradford, B. C. (1991). Perkinsus karlssoni n. sp. (Apicomplexa) in bay scallops Argopecten irradians. Dis. aquat. Org. 10: 127-137

Responsible Subject Editor: A. K. Sparks, Seattle, Washington, USA
O'Donoghue, P. J., Phillips, P. H., Shepherd, S. A. (1991). Perkinsus (Protozoa: Apicomplexa) infections in abalone from South Australian waters. Trans. R. Soc. South. Aust. $115(2): 77-82$

Perkins, F. O. (1985). Range and host extensions for the molluscan bivalve pathogens, Perkinsus spp. Abstract. VII Int Congr. Protozoology, Nairobi, p. 81

Ray, S. M. (1954). Expenmental studies on the transmission and pathogenicity of Dermocystidium marinum, a fungus parasite of oysters. J. Parasitol. 40: 235

Ray, S. M. (1966). A review of the culture method for detecting Dermocystidium marinum, with suggested modifications and precautions. Proc natl. Shellfish. Ass. 54: $55-69$

Ray, S. M. (1987). Salinity requirements of the American oyster, Crassostrea virginica. In: Mueller, A. J., Matthews, G. A. (eds.) Freshwater inflow needs of the Martagorda Bay system with focus on peneid shrimp. U.S. Dept Commerce, NOAA Tech. Mem. NMFS-SEFC-189, Washington DC, p. E.1-E. 28

SAS (1987). SAS/STAT guide for personal computers. Version 6. SAS Institute, Inc., Cary, NC

Spotte, S. (1979). Fish and invertebrate culture. Water management in closed systems. John Wiley \& Sons, New York

White, M. E., Powell, E. N., Ray, S. M., Wilson, E. A. (1987). Host-to-host transmission of Perkinsus marinus in oyster (Crassostrea virginica) populations by the ectoparasitic snail Boonea impressa (Pyramidellidae). J. Shellfish Res. $6(1): 1-5$

Manuscript first received: February 23, 1993

Revised version accepted: July 8, 1993 